\title{
CHEMICAL EXPLOITATION OF METAL CONTAMINATED BIOMASS PRODUCED IN PHYTOEXTRACTION
}

\author{
G. LOSFELD ${ }^{1}$, V. ESCANDE ${ }^{1,2}$, P. VIDAL DE LA BLACHE ${ }^{1,3} \&$ C. GRISON ${ }^{1}$ \\ ${ }^{1}$ Centre d'Ecologie Fonctionnelle et Evolutive, UMR CNRS 5175, F34293 Montpellier, France. \\ ${ }^{2}$ Agence de l'Environnement et de la Maîtrise de l'Energie, 20 avenue du Grésillé, BP 90406, 49004 Angers cedex 1. \\ ${ }^{3}$ Ecole Polytechnique, route de Saclay, 91128 Palaiseau, France.
}

\begin{abstract}
This article describes some aspects of the chemical recovery of the metal contaminated biomass produced in phytoextraction technologies. Taking advantage of the adaptive capacity of certain plants to hyperaccumulate metallic cations in their aerial parts, phytoextraction could be a sustainable way to remediate trace metals pollution. A possible exploitation of the metal contaminated biomass produced in phytoextraction is the direct use of metallic cations derived from plants as Lewis acid catalysts for organic chemistry. These original polymetallic systems serve as heterogeneous catalysts in chemical transformations enabling the synthesis of molecules with high added value. Results for Friedel-Crafts acylations and alkylations are presented in this paper: the acetylation of anisole and benzylation reactions are considered in more detail. The use of mine tailings as catalytic supports is also investigated: it could represent a new integrated outlet for tailings and phytoextraction products. Each step of the process is designed to minimise environmental impacts in accord with the principles of Green Chemistry. The process seeks to be an incentive for the economic development of phytoextraction. As phytoremediation gains momentum, it could also prove a concrete solution to the criticality of non-renewable mineral materials with new sources of zinc, nickel and other metals.

Keywords: Biomass, green and sustainable chemistry, heterogeneous catalysis, hyperaccumulator plants, phytoextraction, trace metals.
\end{abstract}

\section{INTRODUCTION}

Estimations for metal releases in the environment for the period 1950-2000 amount to 22,000 $\mathrm{t}$ for cadmium, 939,000 $\mathrm{t}$ for copper, 783,000 $\mathrm{t}$ for lead and 1,350,000 $\mathrm{t}$ for zinc [1]. Heavy metal pollution needs to be taken very seriously as metals are not biodegradable and tend to bioaccumulate [2]. Contaminated dusts from brownfields may be blown by winds and soil washing may cause the presence of heavy metals in food products or drinking water... Health issues inevitably tail environmental issues when human populations are exposed to heavy metals: nervous diseases, kidneys or lungs malfunctions and bones malformations are clearly linked with heavy metal exposures. The Japanese village of Minamata was a tragic example of the possible impacts of mercury pollution [3]. Heavy metal pollution also directly affects the development potential of the polluted areas and endangers livelihoods: thus many efforts are now focused on reclaiming metal contaminated areas in order to avoid further issues.

Yet, despite their toxicity, heavy metals can also drive evolution through the selective pressure they exert on living organisms: metal tolerant plant species are those able to grow on metal contaminated soils while metal hyperaccumulator species can extract, transport and concentrate metals from soil into their roots and aboveground shoots. By definition, a hyperaccumulator can accumulate at least $1,000 \mathrm{mg} \mathrm{kg}^{-1} \mathrm{Cu}, \mathrm{Pb}$ or $\mathrm{Ni}$, or $10,000 \mathrm{mg} \mathrm{kg}^{-1} \mathrm{Mn}$ or $\mathrm{Zn} \mathrm{[4].} \mathrm{About} 450$ metal hyperaccumulators have been discovered throughout the world with about 360 nickel hyperaccumulators found on ultramafic soils [4]. Where they successfully adapted, endemic metal hyperaccumulator species could be a tool to remediate trace metals pollution. Lately, two zinc-cadmium hyperaccumulators have been discovered in Southeast China [5,6]: this exemplifies the worldwide potential for metal hyperaccumulators. 
New Caledonia is a biodiversity hotspot and hosts dozen of nickel hyperaccumulators: Psychotria douarrei and Geissois pruinosa are two readily available New Caledonian nickel hyperaccumulators that have been used in this study. In the South of France, former mine sites around Saint-Laurentle-Minier also host a very interesting biodiversity: the Ganges ecotype of Thlaspi Caerulescens was found to accumulate $\mathrm{Zn}$ at levels above $10,000 \mathrm{mg} \mathrm{kg}^{-1}$ [7-9] and Anthyllis vulneraria is a zinc hyperaccumulator legume species, which may improve contaminated soil fertility through nitrogen fixation [10]. T. Caerulescens as well as A. Vulneraria from the Les Avinières mine site in SaintLaurent-le-Minier, France have been used in this study.

\section{POTENTIAL OUTLETS FOR CONTAMINATED BIOMASS PRODUCED IN PHYTOEXTRACTION}

\subsection{State of the art methods to reclaim metal contaminated soils}

Decision makers are increasingly considering long-term solutions with lower operating-costs to reclaim land, as the cure may be worse than the ailment in terms of environmental impact [11]. The conventional method to remediate heavy metal pollution is excavation followed by burial at a waste site for an estimated cost of $\$ 400,000$ per treated hectare [12]. At this price, both for mining companies and for the environment, phytoremediation appears as a cost-effective technique to restore metal polluted soils [12]. It also appears as more sustainable, aesthetically more pleasing and boasted better public acceptance where used [1]. Improvements in reputation for industrial stakeholders implementing phytoremediation could also have a non-negligible value although this has not yet been assessed.

Four different phytoremediation methods are usually considered: phytoextraction, rhizofiltration, phytostabilisation and phytovolatilisation [13]. Yet the combination of phytoextraction and phytostabilisation showed the greatest potential [14-16]. Phytostabilisation consists in covering soils with plants able to withstand pollution: the development of the plants' root system contains pollution and prevents soil erosion. Phytoextraction is a biological process where pollutants are extracted from soils and stored by plants (in roots, shoots or both). Wide-scale development of phytoremediation requires agronomic skills: previous examples in Saint-Laurent-le-Minier, France showed that metal tolerant species could successfully prevent soil erosion [17]. In the case of nickel, previous studies showed that phytoextraction was possible with yields good enough to foresee commercial applications [18-20]. Latest studies on former mine sites in the South of France showed a very interesting potential $[10,17]$ but zinc phytoextraction has not yet been subject to field-scale trials.

Thus, phytoextraction is currently raising vivid interest from academics as well as public decision makers. Nevertheless, phytoextraction clearly has its limitations: heavy metal contamination is only shifted from soil to biomass and without reliable outlets for contaminated biomass phytoextraction cannot develop its full potential [21, 22].

\subsection{The issue of the contaminated biomass}

If we rule out landfill as an option to dispose of the contaminated biomass, two main outlets remain: bio-energy production [23] and 'phytomining' [24, 25], an alternative metal production process developed at the United-Stated Department of Agriculture (USDA) for nickel. Other minor outlets also include compost production to supplement metal deficient soils [26] or metal nanoparticle production [27]. 
Although comprehensive economic studies show the potential of bio-energy [23, 28], a large quantity of biomass is required, which leads to restrictions on species used: willow in short-rotation coppice [29], rapeseed, maize and wheat [23] are considered. In the case of zinc phytoextraction, extraction capacity is estimated to range from 5 to $27 \mathrm{~kg}^{-h a^{-1}}$ with willow [29] compared to $60 \mathrm{~kg} . \mathrm{ha}^{-1}$ with T. caerulescens [8]. However, biomass production ranges from 8 to 14 tons per hectare for willow compared to 2.6 tons per hectare for T. caerulescens. This suggests that efficient phytoextraction and bio-energy production cannot be achieved concomitantly. Other drawbacks of bio-energy production from metal contaminated biomass need to be considered: ashes with low metal content remain a problematic waste [18] and technical difficulties to control heavy metal behaviour in the processes involved also exist [30]. Thus bio-energy production is probably more adapted to diffusely polluted soils and does not fully nor specifically address the issue of metal contamination.

In phytomining, nickel hyperaccumulators are considered as a 'bio-ore' and the commercial value of nickel produced could balance the costs involved in the development of phytoextraction [31]. It targets highly contaminated soils and low-grade ores. As leaves need to be burned to ashes in the process, a possible recovery of energy may also be taken into account: expected returns in the best case including nickel and energy production are estimated to $\$ 1,311$ per hectare [24]. However it now seems that phytomining has not met all the expectations it initially raised. The alternative we propose, which is to use the contaminated biomass produced in phytoextraction to produce Lewis acid catalysts for organic chemistry, specifically tackles metal contamination, regardless of the metal considered. It is also compliant with energy recovery but it is conceptually very different from phytomining and could overcome some limits of this technology. Two recently issued international patent applications $[32,33]$ reported preliminary results in the development of this technology.

\subsection{From contaminated biomass to Lewis acid catalysts}

\subsubsection{Treatment of the biomass}

The first description of the biomass treatment process can be found in Losfeld et al. [34]. Our initial challenge was to develop a clean methodology to recover metals from biomass. Our main concern was to avoid the use of hazardous substances such as organic solvents or separation agents. Thus the selection of conditions guided us towards a simple, low-cost and efficient process which is in accord with the principles of green chemistry. Harvested biomass is dried at $60^{\circ} \mathrm{C}$ until a stable weight is achieved ( 3 to $6 \mathrm{~h}$ ). It may then be stored for further use: water content of $T$. caerulescens leaves is estimated to $80 \%$ on average. In the first step of our process, a thermal treatment is applied to the dry biomass at $400^{\circ} \mathrm{C}(5 \mathrm{~h})$ in order to destroy the organic matter. In a second step, the ashes obtained are treated with hydrochloric acid to finish the destruction of the remaining organic compounds and convert metallic species into metal chlorides. The reaction mixture was stirred for $2 \mathrm{~h}$ at $60^{\circ} \mathrm{C}$, and then filtered on celite. The resulting solutions, composed of different metal chlorides, were then concentrated under vacuum and dry residues were stored in a stove at $90^{\circ} \mathrm{C}$ for future laboratory use. Figure 1 summarises the main steps of the process and indicates mass variation in each step.

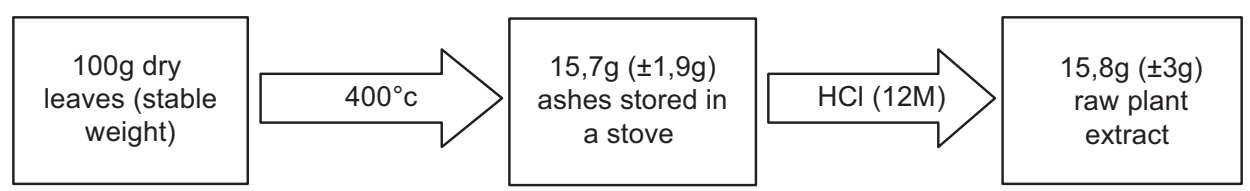

Figure 1: Three main steps of the treatment applied to contaminated biomass and mass variation in each step for T. caerulescens. 
Table 1: Mass of metal (mg) recovered from $1 \mathrm{~g}$ dry $T$. caerulescens ashes.

\begin{tabular}{lllllllll}
\hline & $\mathbf{M g}(\mathbf{I I})$ & $\mathbf{A l}(\mathbf{I I I})$ & $\mathbf{C a}(\mathbf{I I})$ & $\mathbf{F e}(\mathbf{I I I})$ & $\mathbf{C u}(\mathbf{I I})$ & $\mathbf{Z n}(\mathbf{I I})$ & $\mathbf{C d}(\mathbf{I I})$ & $\mathbf{P b}(\mathbf{I I})$ \\
\hline HCl 1 N & 11,7 & 4,3 & 73,1 & 11,5 & 0,2 & 79,2 & 6,9 & 13,5 \\
HCl 12 N & 17,7 & 11,4 & 105,6 & 50,7 & 0,6 & 77,1 & 4,7 & 21,3 \\
\hline
\end{tabular}

Table 2: Metal concentrations (ppm or $\mathrm{mg} \mathrm{kg}^{-1}$ ) in the solid obtained.

\begin{tabular}{lllllllll}
\hline & $\mathbf{M g}(\mathbf{I I})$ & $\mathbf{A l}(\mathbf{I I I})$ & $\mathbf{C a}(\mathbf{I I})$ & $\mathbf{F e}(\mathbf{I I I})$ & $\mathbf{C u}(\mathbf{I I})$ & $\mathbf{Z n}(\mathbf{I I})$ & $\mathbf{C d}(\mathbf{I I})$ & $\mathbf{P b}(\mathbf{I I})$ \\
\hline HCl 1 N & 14,600 & 5,300 & 90,900 & 14,300 & 200 & 98,400 & 8,600 & 16,800 \\
HCl 12 N & 16,900 & 10,900 & 100,600 & 48,300 & 600 & 73,400 & 4,500 & 20,300 \\
\hline
\end{tabular}

In a typical preparation, the volume of $\mathrm{HCl}$ used was $20 \mathrm{ml}$ for $1 \mathrm{~g}$ of ashes to ensure proper stirring of the reaction mixture. Table 1 compares how metal recovery is changed in the case of T. caerulescens when using $1 \mathrm{M} \mathrm{HCl}$ rather than $12 \mathrm{M} \mathrm{HCl}$. Fe(III) and $\mathrm{Al}(\mathrm{III})$ recovery are particularly improved with 4.4-fold and 2.5-fold increases while $\mathrm{Zn}$ (II) recovery is stable. Table 2 show how these differences in metal recovery efficiency translate into concentrations in the solid obtained at the end of the process. The choice of $12 \mathrm{M} \mathrm{HCl}$ was necessary to ensure proper solvation of franklinite $\left(\mathrm{ZnFe}_{2} \mathrm{O}_{4}\right)$ a spinel mineral known for its magnetic properties [35] formed during the thermal treatment of zinc hyperaccumulators biomass. Inductively Coupled Plasma - Mass Spectrometry (ICP-MS) analyses (AETE Platform, Hydrosciences laboratory, Montpellier - France) were used to determine the composition of the various plant extracts obtained from this process.

Other plant extracts were obtained through the process described herein and composition was once again determined by ICP-MS. Wild T. caerulescens and A. vulneraria harvested in Saint-Laurentle-Minier, France were used as a source of zinc while $P$. douarrei from the South Province of New Caledonia was used as a source of nickel. Table 3 summarises the composition of the different plant extracts used in this study.

\subsubsection{Oxidation state of metals}

Previous studies showed that T. caerulescens contained zinc at the degree of oxidation II. Zn(II) is mainly transported as histidine chelates [36] and it is thought to be stored in leaves cells within vacuoles as malate chelates [37]. In our process zinc malate complexes from T. caerulescens are turned into zinc chloride: zinc remains at its initial degree of oxidation (II). Other metallic species are also directly obtained at the targeted degree of oxidation: $\mathrm{Fe}(\mathrm{III})$ and $\mathrm{Al}(\mathrm{III})$ in $T$. caerulescens and A. vulneraria and Ni(II) in P. douarrei [38]. Thus we avoid a potentially costly and technically difficult reduction step, which is required in phytomining to turn metallic cations into metals at the degree of oxidation zero.

\subsubsection{Purification requirements}

Phytomining targets low-grade ores where traditional mining would not be cost-effective [24, 25]: yet the promoted end use, metal production, still requires large quantities of sufficiently pure 'bioore'. On the other hand, in a chemical reaction, a catalyst should be added in small quantities compared to other reagents in order to increase the reaction kinetics and should not be consumed in the reaction. As a general rule, $2 \%$ to $5 \%$ of metal are enough to convert 1 mole of substrate: thus 
Table 3: Composition of the raw hyperaccumulator plant extracts used for organic synthesis (concentrations in $\mathrm{mg} \mathrm{kg}^{-1}$ ).

\begin{tabular}{|c|c|c|c|c|c|}
\hline Catalyst & Mg & Al & $\mathbf{C a}$ & Mn & $\mathbf{F e}$ \\
\hline \multicolumn{6}{|l|}{ T. caerulescens } \\
\hline Concentration & 15,921 & 10,904 & 100,641 & 594 & 48,322 \\
\hline \multicolumn{6}{|l|}{ A. vulneraria } \\
\hline Concentration & 35,876 & 6,015 & 668,579 & 862 & 14,888 \\
\hline \multicolumn{6}{|c|}{ T. caerulescens + A. vulneraria } \\
\hline Concentration & 28,202 & 14,878 & 134,925 & 936 & 27,275 \\
\hline \multicolumn{6}{|c|}{ P. douarrei extract } \\
\hline \multirow[t]{2}{*}{ Concentration } & 20,768 & 5,419 & 96,731 & 1,402 & 5,570 \\
\hline & $\mathbf{N i}$ & $\mathrm{Cu}$ & $\mathbf{Z n}$ & Cd & $\mathbf{P b}$ \\
\hline \multicolumn{6}{|l|}{ T. caerulescens } \\
\hline Concentration & 584 & 409 & 73,443 & 4,475 & 20,320 \\
\hline \multicolumn{6}{|l|}{ A. vulneraria } \\
\hline Concentration & 2,734 & 2,460 & 154,202 & 533 & 11,700 \\
\hline \multicolumn{6}{|c|}{ T. caerulescens + A. vulneraria } \\
\hline Concentration & 2,985 & 523 & 91,232 & 4,845 & 29,249 \\
\hline \multicolumn{6}{|l|}{ P. douarrei } \\
\hline Concentration & 80,153 & 299 & 7,902 & 80 & 703 \\
\hline
\end{tabular}

Lewis acid catalysis does not necessarily require large amounts of metal. Moreover, we expect to benefit from the natural polymetallic composition of the biomass obtained from metal hyperaccumulators: in the case of $T$. caerulescens levels of $\mathrm{Zn}(\mathrm{II})$ and $\mathrm{Fe}$ (III) could be a problem to produce metals $(\mathrm{Zn}(0)$ or $\mathrm{Fe}(0))$ while we may expect additive or synergetic effects of $\mathrm{ZnCl}_{2}$ and $\mathrm{FeCl}_{3}$ as Lewis acids. The polymetallic composition of the plant extracts should also make them more versatile with potential uses in various organic syntheses. Purification steps are not mandatory in our process and when required, partial purifications may be considered to select most active Lewis acids: ion exchange resins could be a tool for solvent-less metal separations.

\section{CHEMICAL EXPLOITATION THROUGH ‘LEWIS ACID’ CATALYSIS}

\subsection{Heterogeneous catalysis: a tool for green chemistry}

New regulations such as REACH (Registration, Evaluation and Authorisation of CHemicals) in the European Union could bring about major changes in chemistry with increased control on health and environmental hazards of chemicals [39]. Influence of networks such as the Green and Sustainable Chemistry Network (GSCN, Japan) could also push for change in processes: the use of catalysis was established as the 9th of the twelve principles of green chemistry [40] and is sometimes referred to catalysis as the foundational pillar of green chemistry [41]. Heterogeneous catalysis (solid catalysts with reagents in liquid phase) is probably the best technique available 
with numerous advantages: smaller quantities of catalyst required, possible catalyst recycling... It also allows the use of fixed bed reactors, which permit reagent recycling and diminish solvent consumption $[42,43]$.

Friedel and Crafts discovered the first electrophilic aromatic substitution 134 years ago: benzene and 1-chloropentane reacted when catalysed by aluminium chloride [44]. The last step of the original process involved a workup implying neutralisation, concomitant generation of water-soluble aluminium salts and extraction to separate organic compounds from salts. The catalyst was destroyed in this final step and large amounts of solvents were required. Today Friedel-Crafts reactions remains the best pathway to produce substituted aromatic compounds and they are still widely used at the laboratory scale as well as at the industrial scale to produce fine chemicals or synthesis intermediates $[45,46]$. The discovery of zeolites, solid acid catalysts that are often alumina-silicate based, gave a new impetus to heterogeneous catalysis at the end of the 1980s [47]. Since then, new improvements appeared: ion exchanged clays and metal halides supported on clays have been investigated since the 1990s [46]. The choice of supporting metal hyperaccumulators extracts on clays was motivated by the very good results obtained with 'clayzic' (commercial zinc chloride supported on montmorillonite K10 clay) an efficient and fully recyclable catalyst $[46,48]$. One of the first reports of nickel chloride supported on montmorillonite K10 was made by Losfeld et al. and taking into account the availability of nickel hyperaccumulators, it seemed necessary to determine the potential of nickel chloride in organic synthesis. We also tested the potential of mine tailings as alternative supports with the idea of developing an integrated approach to the remediation of mining brownfields.

\subsection{Friedel-Crafts alkylations}

Benzylation of aromatic compounds by benzyl chloride is a widely studied Friedel-Crafts alkylation for its products but also as a model for catalysis $[48,49]$. We chose to adapt the process described in Van den Eynde et al. [48] to study benzylation reactions (Fig. 2).

\subsubsection{Choice of the catalytic support}

In addition to montmorillonite K10 which is a commonly used catalytic support we also decided to investigate the properties of other potential supports: sand from the tailing ponds of the Les Avinières mine site in Saint-Laurent-le-Minier, France [9] (named Avinières sand), laterite and nickel mine tailings from New Caledonia were considered. These potential supports presented the following activities in toluene benzylation (Table 4).

Due to their activity in the reaction, laterite and Avinières sand should be considered as catalysts per se rather than catalytic supports. Thus we decided to restrict our investigations to nickel mine tailings and montmorillonite K10. According to entries 8 and 9 in Table 5 Montmorillonite K10 proved a good catalytic support for commercial zinc chloride in accord with literature examples [48]. It also appeared to be a good support for commercial nickel chloride. However nickel mine tailings could not successfully support commercial metal halides (Table 5, entries 6 and 7). Further investigations on the composition and physical structure of these tailings should corroborate these findings.

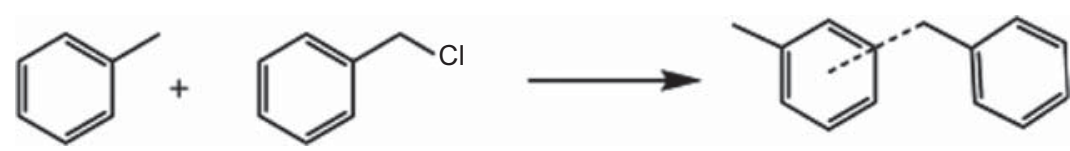

Figure 2: Toluene benzylation using benzyl chloride. 
Table 4: Activity of potential catalytic supports in toluene benzylation.

\begin{tabular}{llc}
\hline Entry & Support $(\mathbf{0 . 2} \mathbf{g})$ & Yield $\mathbf{( 1 ~ h ) ~}$ \\
\hline $\mathbf{1}$ & None & $1 \%$ \\
$\mathbf{2}$ & Nickel mine tailings & $1 \%$ \\
$\mathbf{3}$ & Montmorillonite K10 & $8 \%$ \\
$\mathbf{4}$ & Avinières sand & $90 \%$ \\
$\mathbf{5}$ & Laterite & $100 \%$ \\
\hline
\end{tabular}

Table 5: Catalytic supports used with commercial metal halides for toluene benzylation.

\begin{tabular}{llcc}
\hline Entry & Catalyst $(\mathbf{0 . 1 5} / \mathbf{0 . 2 0}$ g) & $\begin{array}{c}\text { Catalyst/Benzyl chloride } \\
\text { (equivalent) }\end{array}$ & Yield (1 h) \\
\hline $\mathbf{6}$ & $\mathrm{ZnCl}_{2}$ on tailings & 0.61 & $0 \%$ \\
$\mathbf{7}$ & $\mathrm{NiCl}_{2}$ on tailings & 0.63 & $0 \%$ \\
$\mathbf{8}$ & $\mathrm{ZnCl}_{2}$ on $\mathrm{K} 10$ & 0.61 & $100 \%$ \\
$\mathbf{9}$ & $\mathrm{NiCl}_{2}$ on $\mathrm{K} 10$ & 0.63 & $46 \%$ \\
\hline
\end{tabular}

\subsubsection{Use of metal hyperaccumulator plant extracts}

Toluene benzylation was then conducted using raw metal hyperaccumulators extracts: T. caerulescens and A. vulneraria were used as a source of zinc chloride while $P$. douarrei was used as a source of nickel chloride. The composition of the plant extracts used is presented in Table 4. Yields obtained in toluene benzylation are summarised in Tables 6 and 7. Ortho as well as para isomers are obtained but the ortho to para ratio is not indicated as it remained stable at 0.75 (43\% ortho and $57 \%$ para) in every batch.

Tables 6 and 7 show how metal chlorides concentrations in plant extracts translate into equivalent metal chloride in the conditions used. Zinc hyperaccumulators seem to work better than commercial zinc chloride as a lesser quantity of Lewis acid gave the same yield (Table 6, entry 10). The case of P. douarrei and G. pruinosa is different as $\mathrm{NiCl}_{2}$ is the main Lewis acid present: it is known to be a modest Lewis acid and it is only present at concentrations close to 80,000pp. (8\%). However with 0.27 total equivalent metal chlorides it is still possible to obtain interesting yields in 3 hours (Table 7 , entries 11 and 12). Ortho/para ratios are in accord with what is usually observed with montmorillonitesupported catalysts. If we compare these results with those obtained with other catalysts, taking into account the simplicity of the process involved to produce the catalyst and the mild reaction conditions, it appears that plant extracts supported on montmorillonite K10 do well: Cseri et al. [49] reported total toluene benzylation in $3 \mathrm{~h}$ at $80^{\circ} \mathrm{C}$ using ion exchanged montmorillonite K10. More recently, Choudhary et al. [50] reported $80 \%$ yield in toluene benzylation using benzyl chloride in 25 minutes at $110^{\circ} \mathrm{C}$ using a In-Mg-hydrotalcite anionic clay.

\subsubsection{Other electrophilic aromatic substitutions}

To prove the efficiency of our catalytic system, it was also tested with other reagents (Fig. 3, Table 8), such as anisole (entry 16), benzene (entries 13-15), chlorobenzene (entries 19-21), 1,4-dimethylbenzene (entry 17), 1,2-diethylbenzene (entry 18). The reaction was satisfactory with 
Table 6: Yields in toluene benzylation using zinc chloride or zinc hyperaccumulators extracts.

\begin{tabular}{llccc}
\hline Entry & Catalyst $(\mathbf{0 . 1 5 / 0 . 2 0} \mathbf{g})$ & $\mathbf{Z n C l}_{\mathbf{2}}$ & $\begin{array}{c}\mathbf{Z n C l}_{\mathbf{2}}+\mathbf{F e C l}_{\mathbf{3}} \\
+\mathbf{A l C l}_{\mathbf{3}}+\mathbf{N i C l}_{\mathbf{2}} \mathbf{~ e q}\end{array}$ & Yield (1 h) \\
\hline $\mathbf{1}$ & None & - & - & $1 \%$ \\
$\mathbf{3}$ & $\mathrm{K} 10(0.2 \mathrm{~g})$ & - & - & $10 \%$ \\
$\mathbf{6}$ & $\mathrm{ZnCl}$ on $\mathrm{K} 10$ & 0.61 & 0.61 & $100 \%$ \\
$\mathbf{1 0}$ & A. vulneraria on $\mathrm{K} 10$ & 0.35 & 0.43 & $100 \%$ \\
\hline
\end{tabular}

Table 7: Yields in the toluene benzylation using nickel chloride and nickel hyperaccumulators extracts.

\begin{tabular}{llccc}
\hline Entry & Catalyst $(\mathbf{0 . 1 5 / 0 . 2 0 ~ g )}$ & $\mathbf{N i C l}_{\mathbf{2}} \mathbf{~ e q}$ & $\begin{array}{r}\mathbf{Z n C l}_{\mathbf{2}}+\mathbf{F e C l}_{\mathbf{3}} \\
+\mathbf{A l C l}_{\mathbf{3}}+\mathbf{N i C l}_{\mathbf{2}} \mathbf{~ e q}\end{array}$ & Yield (3 h) \\
\hline $\mathbf{7}$ & $\mathrm{NiCl}_{2}$ on $\mathrm{K} 10$ & 0.63 & 0.63 & $35 \%$ \\
$\mathbf{1 1}$ & P. douarrei on $\mathrm{K} 10(\mathrm{NiCl} 2)$ & 0.21 & 0.26 & $40 \%$ \\
$\mathbf{1 2}$ & G. Pruinosa on $\mathrm{K} 10$ & 0.19 & 0.27 & $50 \%$ \\
\hline
\end{tabular}

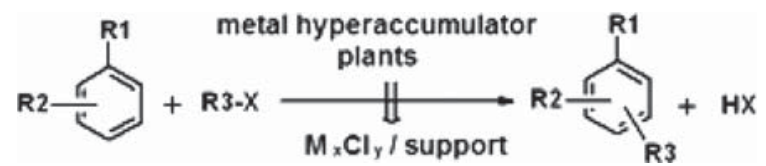

Figure 3: Friedel-Crafts alkylation catalysed by metal hyperaccumulator plants extracts.

deactivating substituents if the catalyst derived from T. caerulescens or the mixture T. caerulescens + A. vulneraria (entries 19-21). The benzylation of 1,4-dimethyl- and 1,2-diethylbenzene were carried out with good yields (entries 17 and 18). The steric hindrance did not modify the efficiency and no polybenzylation was observed.

It is then of particular interest to use plant-based catalysts in multi-step syntheses. 1-chloro 1-phenyl propane being a useful starting material in EAS, it has been the object of a particular study. Under the conditions described in Grison \& Escarré $[32,33]$ T. caerulescens was able to catalyse the chlorination of 1-phenyl 1-propanol (Fig. 4). As expected, the obtained chloride derivative was benzylated with the same catalyst in $31 \%$ yield over two steps.

\subsubsection{Protocol for benzylation reactions}

Our protocol is adapted from Van den Eynde et al. [48]. Plant extracts obtained through the process described in this article replaced commercial $\mathrm{ZnCl}_{2}$ and montmorillonite $\mathrm{K} 10$ was obtained from Alfa-Aesar. In a typical experiment, $200 \mathrm{mg}$ of montmorillonite $\mathrm{K} 10$ was placed in a mortar and airdried. $150 \mathrm{mg}$ plant extract were then added and mixed with montmorillonite K10 using a pestle to obtain a homogeneous powder. This powder was then put in a dry round-bottom flask in which $20 \mathrm{mmol}$ arene and $1 \mathrm{mmol}$ benzyl chloride were added. The reaction mixture was stirred magnetically. Samples taken to monitor the reaction were diluted in dichloromethane before GC-MS analysis. 


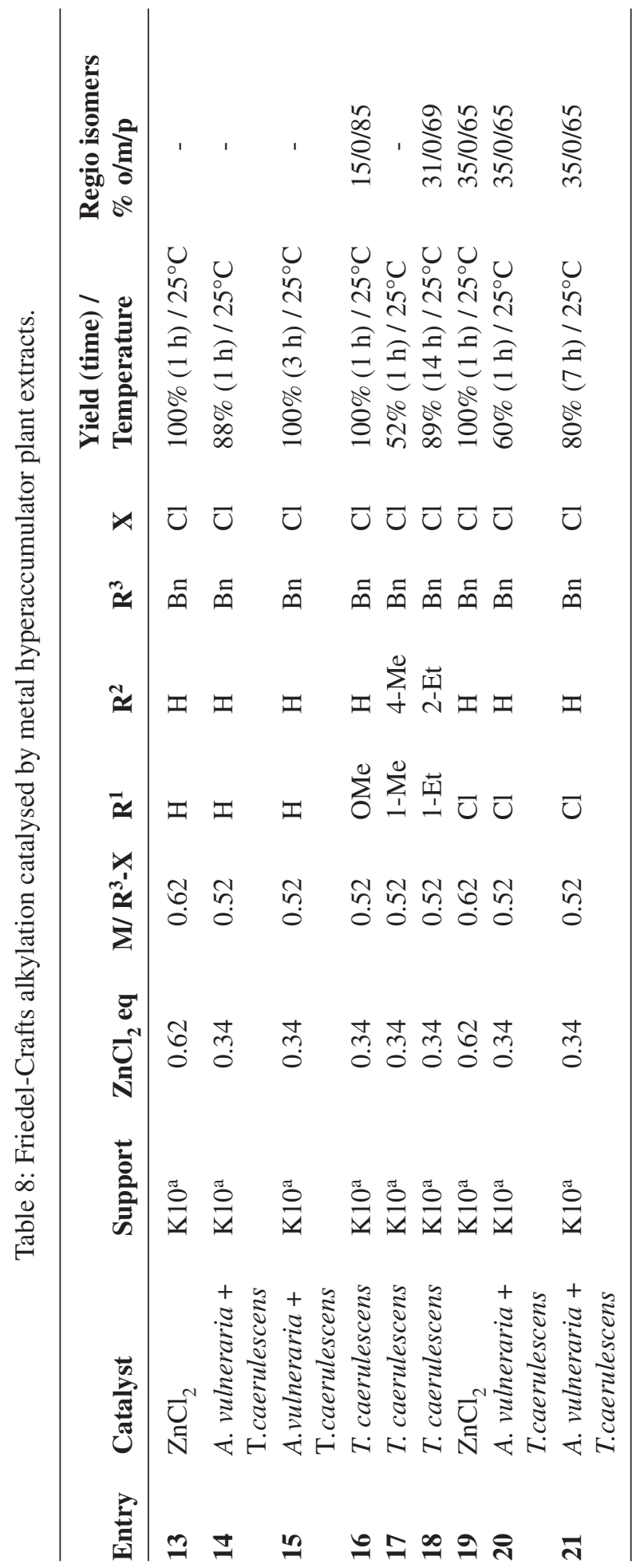


<smiles>CCC(O)c1ccccc1</smiles><smiles>CC(C)=C(C)C</smiles><smiles>CCC(Cl)c1ccccc1</smiles>

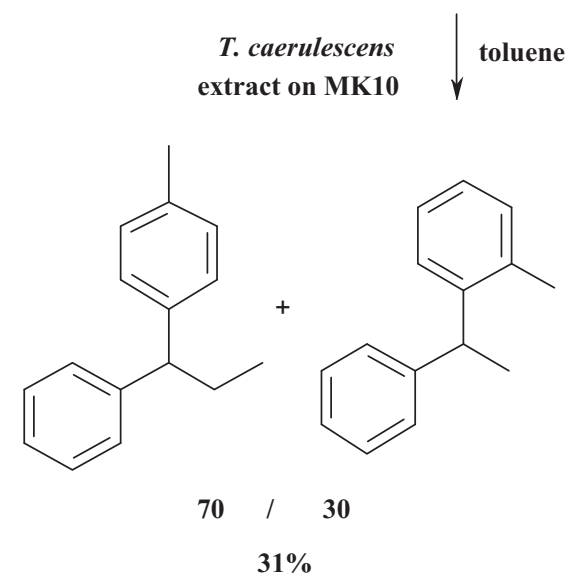

Figure 4: Preparation of 1-toluyl 1-phenyl propane in two steps catalysed by T. caerulescens extracts.

Table 9: Yields in phenolphthalein and fluorescein synthesis.

\begin{tabular}{llccl}
\hline Entry & Reaction & Time (min) & Yield & Test \\
\hline $\mathbf{1}$ & Phenolphthalein & 5 & $90 \%$ & pH 8 \\
$\mathbf{2}$ & Fluorescein & 5 & $90 \%$ & UV lamp \\
\hline
\end{tabular}

An electronic impact ionisation mode on a Varian Saturn 2000 ion trap instrument, interfaced with a Varian CP-3800 apparatus. The Varian CP-3800 was equipped with a 1079 split-splitless injector $\left(206^{\circ} \mathrm{C}\right)$ and a $30 \mathrm{~m} \times 0.25 \mathrm{~mm} \times 0.25 \mathrm{~m}$ film thickness ID WCOT CPSil-8CB fused silica capillary column (Chrompack ${ }^{\circledR}$, Bergen op Zoom, The Netherlands), with helium as carrier gas $(1 \mathrm{~mL} / \mathrm{min})$, and programmed $4 \mathrm{~min}$ isothermal at $70^{\circ} \mathrm{C}$, then increasing from $70^{\circ} \mathrm{C}$ to $160^{\circ} \mathrm{C}$ at $5^{\circ} \mathrm{C} / \mathrm{min}$ and finally from $160^{\circ} \mathrm{C}$ to $190^{\circ} \mathrm{C}$ at $15^{\circ} \mathrm{C} / \mathrm{min}$. Mass spectra were recorded in electronic impact (EI) at $70 \mathrm{eV}$, and identified by comparison with data of the NIST 98 software library (Varian, Palo Alto, CA, USA) and by comparison of the retention time of the standard compounds.

\subsection{Friedel-Crafts acylations}

\subsubsection{Results for phenolphthalein and fluorescein synthesis}

The synthesis of phenolphthalein and fluorescein were investigated in homogeneous catalysis using raw catalysts drawn from $T$. caerulescens containing majorly $\mathrm{ZnCl}_{2}$ (Fig. 5). Table 9 summarises the results:

T. caerulescens extracts therefore proved to be a very good catalyst for the synthesis of phenolphthalein and fluorescein, two important indicators for chemistry. The high yield in a short period of 


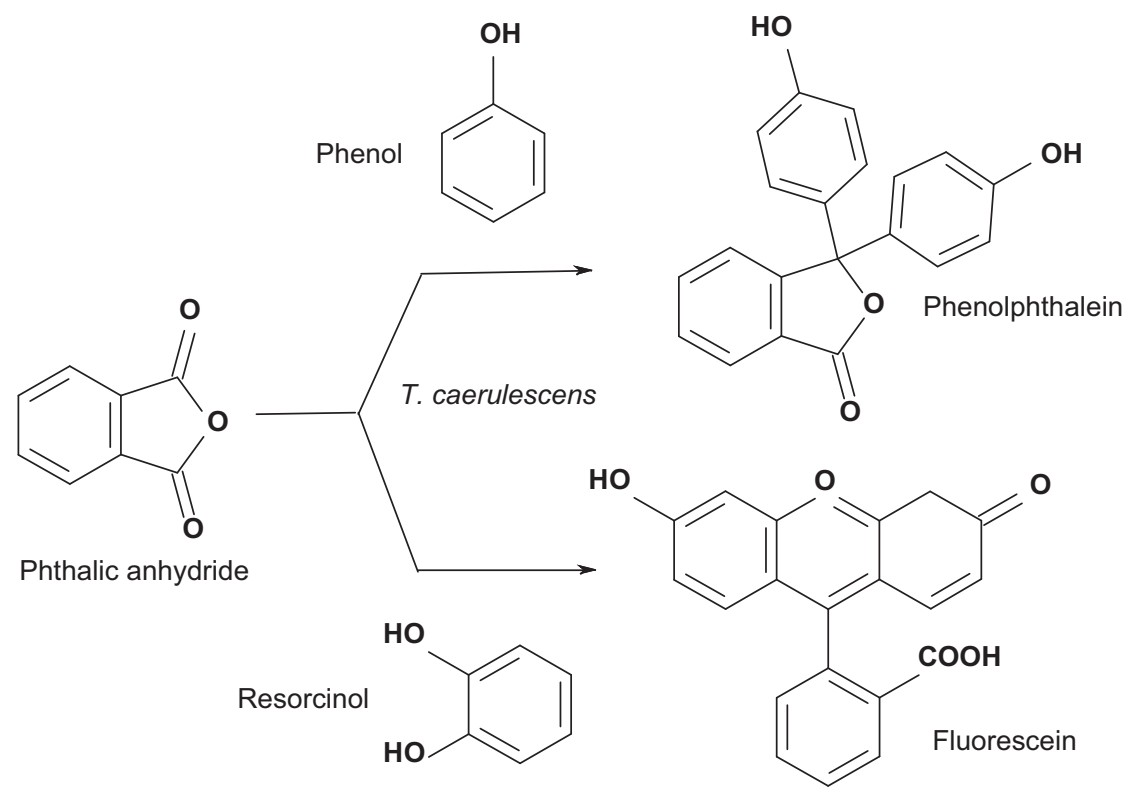

Figure 5: Synthesis of phenolphthalein and fluorescein using T. caerulescens extract.

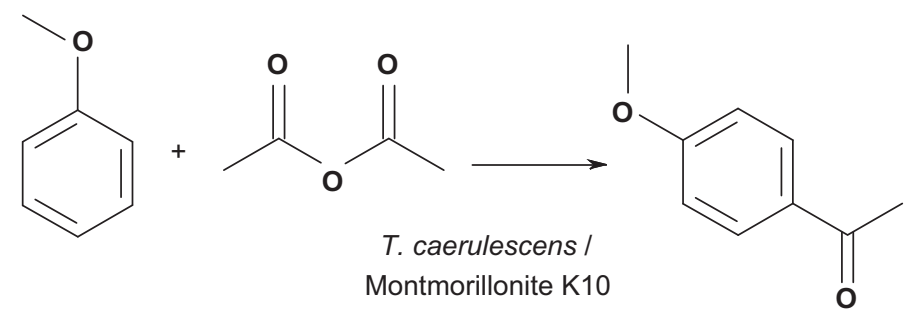

Figure 6: Acetylation of anisole using acetic anhydride over T. caerluscens extracts supported on montmorillonite K10.

time and the fact that the plant extract did not undergo any ulterior transformations show the interesting capabilities of such a process.

3.3.2 Choice of the catalytic support for the acetylation of anisole

Similarly to our toluene benzylation, we investigated different possible catalytic supports for the acetylation of anisole. As the acetylation of anisole is known to be more resistant than toluene benzylation the quantity of support used was increased to $1,5 \mathrm{~g}$. Table 10 summarises the activities of the different supports in the acetylation of anisole.

These potential supports were then tested using commercial zinc chloride or nickel chloride. As entries 6 and 7 in Table 9 show it, New Caledonian mine tailings once again failed to be good supports for metal halides. Avinières sand on the other hand proved a good support for zinc chloride (Table 11, entry 9) while montmorillonite K10 proved a good support for zinc chloride as well as nickel chloride (Table 11, entries 8 and 10). 
Table 10: Potential catalytic supports for the acetylation of anisole.

\begin{tabular}{llc}
\hline Entry & Support $(\mathbf{1 , 5} \mathbf{g})$ & Yield $(\mathbf{1 5} \mathbf{h})$ \\
\hline $\mathbf{1}$ & None & $0 \%$ \\
$\mathbf{2}$ & Nickel mining tailings & $0 \%$ \\
$\mathbf{3}$ & Montmorillonite K10 & $0 \%$ \\
$\mathbf{4}$ & Avinières sand & $1 \%$ \\
$\mathbf{5}$ & Laterite & $60 \%$ \\
\hline
\end{tabular}

Table 11: Catalytic supports used with commercial zinc or nickel chloride

\begin{tabular}{llcc}
\hline Entry & Catalyst $\mathbf{( 1 ~ g / 1 , 5 ~ g ) ~}$ & $\begin{array}{c}\text { Catalyst/Benzyl chloride } \\
\text { (equivalent) }\end{array}$ & Yield (15 h) \\
\hline $\mathbf{6}$ & $\mathrm{ZnCl}_{2}$ on tailings & 2,6 & $0 \%$ \\
$\mathbf{7}$ & $\mathrm{NiCl}_{2}$ on tailings & 2,8 & $0 \%$ \\
$\mathbf{8}$ & $\mathrm{ZnCl}_{2}$ on $\mathrm{K} 10$ & 2,6 & $100 \%$ \\
$\mathbf{9}$ & $\mathrm{ZnCl}_{2}$ on Avinières sand & 2,6 & $100 \%$ \\
$\mathbf{1 0}$ & $\mathrm{NiCl}_{2}$ on $\mathrm{K} 10$ & 2,8 & $80 \%$ \\
\hline
\end{tabular}

3.3.3 Results for the acetylation of anisole

Acetylation of anisole was investigated in heterogeneous catalysis using raw plant extracts drawn from $T$. caerulescens (containing majorly $\mathrm{ZnCl}_{2}$ ) and $P$. douarrei (containing majorly $\mathrm{NiCl}_{2}$ ) and commercial $\mathrm{ZnCl}_{2}$ and $\mathrm{NiCl}_{2}$ supported on montmorillonite $\mathrm{K} 10$ (Fig. 6). Results are summarised in Tables 12 and 13. In heterogeneous phase the para/ortho ratio rises dramatically, which is an effect mentioned in the literature that we also observed [51]. This is due to a rearrangement of the product towards the more thermodynamically stable para compound. $\mathrm{ZnCl}_{2}$ in a homogeneous reaction is known as a modest catalyst which is why $\mathrm{AlCl}_{3}$ and $\mathrm{FeCl}_{3}$ are preferred industrially. However the difficulties encountered while dehydrating $\mathrm{AlCl}_{3}$ and $\mathrm{FeCl}_{3}$ or $\mathrm{ZnCl}_{2}$ (rapid caking after dehydration) might explain why some catalyst may not enter the liquid organic phase. These difficulties to manipulate $\mathrm{ZnCl}_{2}$ justify ipso facto supporting it on montmorillonite or silica. The reactions carried out using raw catalysts drawn from $T$. caerulescens show that the reaction product can be obtained quantitatively when there are more than 2 equivalents present in the solid catalyst. Moreover, the raw catalyst shows results equivalent to commercial $\mathrm{ZnCl}_{2}$, confirming the good reactivity and potential of these green, polymetallic catalysts. The other interesting results concern 'green' catalysts containing $\mathrm{NiCl}_{2}$, which is an unusual Lewis acid for this reaction. To our knowledge, its use has never been reported for the acetylation of anisole. Entry 8 shows that raw catalysts drawn from $P$. douarrei show lower but interesting yields (considering the fact that it is seldom used in this reaction) when compared to those of catalysts drawn from T. caerulescens. Moreover, the yields are higher for 'green' poly-metallic catalysts than they are for commercial $\mathrm{NiCl}_{2}$ catalysts even despite having two times less equivalent active species. This is an important result for this reaction but also on a more theoretical level: this shows the advantage of polymetallic catalytic systems over monometallic catalysts, a result presented in Corma \& Garcia [47]. 
Table 12: Yields in the acetylation of anisole using zinc chloride or zinc hyperaccumulators extracts.

\begin{tabular}{|c|c|c|c|c|c|c|c|}
\hline \multirow[b]{2}{*}{ Entry } & \multirow[b]{2}{*}{ Catalyst } & \multicolumn{2}{|c|}{ Catalyst/Ac $\mathbf{A}_{2} \mathrm{O}$ (equivalent) } & \multicolumn{4}{|c|}{ Yield } \\
\hline & & $\mathrm{ZnCl}_{2}$ & Total & $1 \mathrm{~h}$ & $3 \mathbf{h}$ & $6 \mathrm{~h}$ & $15 \mathrm{~h}$ \\
\hline 3 & $\mathrm{~K} 10(1.5 \mathrm{~g})$ & - & - & & & & $0 \%$ \\
\hline 10 & $\mathrm{ZnCl}_{2}(1 \mathrm{~g})$ in liquid phase & 2,6 & 2,6 & $52 \%$ & $100 \%$ & $100 \%$ & $100 \%$ \\
\hline 11 & & 1,3 & 1,3 & $42 \%$ & $100 \%$ & $100 \%$ & $100 \%$ \\
\hline 8 & $\mathrm{ZnCl}_{2}$ on $\mathrm{K} 10$ & 2,6 & 4.6 & $71 \%$ & $79 \%$ & $100 \%$ & $100 \%$ \\
\hline 12 & & 1,3 & 1,3 & & & $100 \%$ & $100 \%$ \\
\hline 13 & T. caerulescens on $\mathrm{K}-10$ & 0.85 & 1.24 & $4 \%$ & $43 \%$ & $100 \%$ & $100 \%$ \\
\hline 14 & & 0.43 & 0.62 & & & & $20 \%$ \\
\hline
\end{tabular}

Table 13: Yields in the acetylation of anisole using nickel chloride or nickel hyperaccumulators extracts.

\begin{tabular}{|c|c|c|c|c|c|}
\hline \multirow[b]{2}{*}{ Entry } & \multirow[b]{2}{*}{ Catalyst } & \multicolumn{2}{|c|}{ Catalyst/Ac $\mathbf{A}_{2} \mathrm{O}$ (equivalent) } & \multicolumn{2}{|c|}{ Yield } \\
\hline & & $\mathrm{NiCl}_{2}$ & Total & $6 \mathrm{~h}$ & $15 \mathrm{~h}$ \\
\hline 3 & $\mathrm{~K}-10(1.5 \mathrm{~g})$ & - & - & - & $0 \%$ \\
\hline 15 & $\mathrm{NiCl}_{2}(1 \mathrm{~g})$ in liquid phase & 2,8 & 2,8 & $44 \%$ & $81 \%$ \\
\hline 10 & $\mathrm{NiCl}_{2}$ on $\mathrm{K}-10(1 \mathrm{~g} / 1.5 \mathrm{~g})$ & 2,8 & 2,8 & $78 \%$ & $80 \%$ \\
\hline 16 & P. douarrei on K-10 (1 g/1.5 g) & 0.85 & 1.1 & $84 \%$ & $85 \%$ \\
\hline
\end{tabular}

\subsubsection{Preparation of phenolphthalein}

Phthalic anhydride $(500 \mathrm{mg})$ was added at $80^{\circ} \mathrm{C}$ to $500 \mathrm{mg}$ of phenol with $1 \mathrm{~g}$ of raw catalyst drawn from T. caerulescens (dried for several minutes at $110^{\circ} \mathrm{C}$ ). The mixture was stirred for 5 minutes. After cooling the mixture, it is diluted in $5 \mathrm{ml}$ of an $\mathrm{H}_{2} \mathrm{O}$ /ethanol mixture. $1 \mathrm{ml}$ is sampled and added to $3 M$ sodium hydroxide: if the reaction took place, the mix becomes immediately pink. After washing with ether, phenolphthalein crystallises easily.

\subsubsection{Preparation of fluorescein}

Phthalic anhydride $(500 \mathrm{mg})$ was added at $80^{\circ} \mathrm{C}$ to $1 \mathrm{~g}$ of resorcinol with $2 \mathrm{~g}$ of raw catalyst drawn from T. caerulescens (dried for several minutes at $110^{\circ} \mathrm{C}$ ). The mixture was stirred for 5 minutes. After cooling the mixture, it is diluted in $5 \mathrm{ml}$ of an $\mathrm{H}_{2} \mathrm{O}$ /ethanol mixture. $1 \mathrm{ml}$ is sampled and added to $3 M$ sodium hydroxide: if the reaction took place and the mix is added to a diluted solution of ammonia, a bright yellow solution confirms the formation of fluorescein. After washing with ether, fluorescein crystallises easily.

\subsubsection{Preparation of 4-methoxy-acetophenone}

In heterogeneous catalysis, the catalyst $(1 \mathrm{~g})$ was dried prior to the reaction and supported on montmorillonite $\mathrm{K} 10(1,5 \mathrm{~g})$ in a typical procedure adapted from Gupta et al. [52]. Acetic anhydride (0.30 or $0.15 \mathrm{ml}$ ) was added under $\mathrm{N}_{2}$, at $70^{\circ} \mathrm{C}$, to $3 \mathrm{ml}$ of anhydrous anisole with the supported catalyst. The mixture was stirred for 3,6 or 15 hours. The thick mixture is then filtered to recover the catalyst 
and washed with dichloromethane $(20 \mathrm{ml})$. An internal standard (nitrobenzene, respectively $0.32 \mathrm{ml}$ or $0.16 \mathrm{ml}$ ) was added to measure progress of the reaction using Gas Chromatography - Mass Spectrometry (GC-MS) with the conditions stated before.

\section{CONCLUSION AND PERSPECTIVES}

Phytoextraction is now considered as the most publicly accepted and sustainable method to remediate heavy metals pollution. However, to be fully applicable this innovative technique needs strong incentives: more research needs to be carried out on the ecology of metal hyperaccumulators and agronomic techniques need to be developed. So far it appears that existing techniques cannot give phytoextraction sufficient momentum to lead to a generalisation of the process to reclaim mining brownfields. The alternative we propose, using metal hyperaccumulator plants species to produce Lewis acid catalysts for organic synthesis could bring about change as it is probably more adapted to the state of metallic species present in plant tissues. It could bring extra added value to the contaminated biomass produced. In terms of organic synthesis, perspectives are various and include hydrochlorinations of alcohols, synthesis of aromatic heterocycle scaffolds, chiral cyclic structures, protections of alcohols and amines, aldolisations, metal catalysed rearrangements and other key syntheses of industrial and fine chemistry.

\section{ACKNOWLEDGEMENTS}

The authors gratefully acknowledge financial support from the Centre National de la Recherche Scientifique (CNRS), the PIR-CNRS-CEMAGREF INGECOTECH and the ANR (11ECOT01101) and two Grants from the Ecole Polytechnique, Palaiseau and ADEME. They also thank Jacques Bessiere and Yves Pillet for the polarographic studies, (UHP Nancy I), Bruno Buatoisadsdsdss for the CEFE platform of chemical analysis, Eddy Petit (IEM/UM2 UMR 5635) for the NMR analysis and Rémi Freydier (Hydrosciences laboratory / AETE platform/UM2) for the ICP-MS analysis.

\section{REFERENCES}

[1] Singh, O.V., Labana, S., Pandey, G. \& Budhiraja, R. Phytoremediation: an overview of metallic ion decontamination from soil. Applied Microbiology and Biotechnology, 61(5-6), pp. 405-412, 2003. doi: http://dx.doi.org/10.1007/s00253-003-1244-4

[2] Hédouin, L., Pringault, O., Metian, M., Bustamante, P. \& Warnau, M., Nickel bioaccumulation in bivalves from the New Caledonia lagoon: seawater and food exposure, Chemosphere, 66(8), pp. 1449-1457, 2007. doi: http://dx.doi.org/10.1016/j.chemosphere.2006.09.015

[3] Harada, M., Minamata disease: methylmercury poisoning in Japan caused by environmental pollution. Critical Reviews in Toxicology, 25(1), pp. 1-24, 1995. doi: http://dx.doi. org/10.3109/10408449509089885

[4] Reeves, R.D. \& Baker, A.J.M., Metal-accumulating plants. Phytoremediation of Toxic Metals: Using Plants to Clean up the Environment, eds. Ilya Raskin \& Burt D. Ensley, John Wiley and Sons: New York, 2000.

[5] Xua, L., Zhou, S., Wu, L., Li, N., Cu, L., Luo, Y. \& Christie, P., Cd and Zn tolerance and accumulation by Sedum jinianum in East China. International Journal of Phytoremediation, 11(3), pp. 283-295, 2009. doi: http://dx.doi.org/10.1080/15226510802432744

[6] Jiang, J., Wu, L., Li, N., Luo, Y., Liu, L., Zhao, Q., Zhang, L. \& Christie, P., Effects of multiple heavy metal contamination and repeated phytoextraction by Sedum plumbizincicola on soil microbial properties. European Journal of Soil Biology, 46(1), pp. 18-26, 2010. doi: http:// dx.doi.org/10.1016/j.ejsobi.2009.10.001 
[7] Zhao, F.-J. Hamon, R.E., Lombi, E., McLaughlin, M.J. \& McGrath, S.P., Characteristics of cadmium uptake in two contrasting ecotypes of the hyperaccumulator Thlaspi caerulescens. Journal of Experimental Botany, 53(368), pp. 535-543, 2002. doi: http://dx.doi.org/10.1093/ jexbot/53.368.535

[8] Robinson, B.H., Leblanc, M., Petit, D., Brooks, R.R., Kirkman, J.H. \& Gregg, P.E.H., The potential of Thlaspi caerulescens for phytoremediation of contaminated soils. Plant and Soil, 203(1), pp. 47-56, 1998. doi: http://dx.doi.org/10.1023/A:1004328816645

[9] Escarré, J., Lefèbvre, C., Raboyeau, S., Dossantos, A., Gruber, W., Cleyet-Marel, J.C., Frérot, H., Noret, N., Mahieu, S., Collin, C. \& van Oort, F., Heavy Metal Concentration Survey in Soils and Plants of the Les Malines Mining District (Southern France): implications for Soil Restoration. Water Air \& Soil Pollution, 216, pp. 485-504, 2011.doi: http://dx.doi.org/10.1007/ s11270-010-0547-1

[10] Mahieu, S., Frérot, H., Vidal, C., Galiana, A., Heulin, K., Maure, L., Brunel, B., Lefèbvre, C., Escarré, J. \& Cleyet-Marel, J.C., Anthyllis vulneraria/Mesorhizobium metallidurans, an efficient symbiotic nitrogen fixing association able to grow in mine tailings highly contaminated by $\mathrm{Zn}, \mathrm{Pb}$ and Cd. Plant and Soil, 342(1-2), pp. 405-417, 2011.doi: http://dx.doi.org/10.1007/ s11104-010-0705-7

[11] Harbottle, M.J., Al-Tabbaa, A. \& Evans, C.W., Assessing the true technical / environmental impacts of contaminated land remediation - a case study of containement, disposal and no-action. Land Contamination and Reclamation, 14, pp. 85-99, 2006. doi: http://dx.doi. org/10.2462/09670513.700

[12] Glass, D.J., Economic Potential of Phytoremediation, Phytoremediation of Toxic Metals: Using Plants to Clean up the Environment, eds. Ilya Raskin \& Burt D. Ensley, John Wiley and Sons: New York, 2000.

[13] Berti W.R. \& Cunningham, S.D., Phytostabilization of metals. Phytoremediation of Toxic Metals: Using Plants to Clean up the Environment, eds. B. Ensley \& I. Raskin, John Wiley \& Sons: New York, 1999. doi: http://dx.doi.org/10.1007/s11356-009-0205-6

[14] Bert, V., Seuntjens, P., Dejonghe, W., Lacherez, S., Thi Thanh Thuy, H. \& Vandecasteele, B., Phytoremediation as a management option for contaminated sediments in tidal marshes, flood control areas and dredged sediment landfill sites. Environmental Science and Pollution Research, 16, pp. 745-764, 2009. doi: http://dx.doi.org/10.1007/s11356-009-0252-z

[15] Mench, M., Schwitzguébel, J.P., Schroeder, P., Bert, V., Gawronski, S. \& Gupta, S., Assessment of successful experiments and limitations of phytotechnologies: contaminant uptake, detoxification and sequestration, and consequences for food safety. Environmental Science and Pollution Research, 16(7), pp. 876-900, 2009. doi: http:://dx.doi.org/10.1007/s11368-010-0190-x

[16] Mench, M., Lepp. N., Bert, V., Schwitzguébel, J.P., Gawronski, S.W., Schröder, P. \& Vangronsveld, J., Successes and limitations of phytotechnologies at field scale:outcomes, assessment and outlook from COST Action 859. Journal of Soils and Sediments, 6(10), pp. 1039-1070, 2010.

[17] Frérot, H., Lefèbvre, C., Gruber, W., Collin, C., Santos, A. \& Escarré, J., Specific interactions between local metallicolous plants improve the phytostabilization of mine soils. Plant and Soil, 282(1-2), pp. 53-65, 2006. doi: http://dx.doi.org/10.1007/s11104-005-5315-4

[18] Li, Y.-M., Chaney, R.L., Brewer, E., Roseberg, R., Angle, J.S., Baker, A.J.M., Reeves, R.D. \& Nelkin, J., Development of a technology for commercial phytoextraction of nickel: economic and technical considerations. Plant and Soil, 249(1), pp. 107-115, 2003. doi: http://dx.doi. org/10.1023/A:1022527330401

[19] Chaney, R.L., Angle, J.S., Mcintosh, M.S. \& Reeves, R.D., Using hyperaccumulator plants to phytoextract soil Ni and Cd. Z. Naturforsch, 60c, pp. 190-198, 2005. 
[20] Bani, A., Echevarria, G., Sulçe, S., Morel, J.-L. \& Mullai, A., In-situ phytoextraction of Ni by a native population of Alyssum murale on an ultramafic site (Albania). Plant and Soil, 293(1-2), pp. 79-89, 2007. doi: http://dx.doi.org/10.1007/s11104-007-9245-1

[21] Whiting, S.N., Reeves, R.D., Richards, D., Johnson, M.S., Cooke, J.A., Malaisse, F., Paton, A., Smith, J.A.C., Angle, J.S., Chaney, R.L., Ginicchio, R., Jaffré, T., Johns, R., Mcintyre, T., Purvis, O.W., Salt, D.E., Schat, H., Zhao, F.J. \& Baker, A.J.M., Research priorities for conservation of metallophyte biodiversity and their potential for restoration and site remediation. Restoration Ecology, 12(1), pp. 106-116, 2004. doi: http://dx.doi.org/10.1111/j.10612971.2004.00367.x

[22] Sas-Nowosielska, A., Kucharski, R., Malkowski, E., Pogrzeba, M., Kuperberg, J.M. \& Krynski, K., Phytoextraction crop disposal—an unsolved problem. Environmental Pollution, 128(3), pp. 373-379, 2004. doi: http://dx.doi.org/10.1016/j.envpol.2003.09.012

[23] Van Ginneken, L., Meers, E., Guisson, R., Ruttens, A., Elst, K., Tack, F.M.G., Vangronsveld, J., Diels, L. \& Dejonghe, W., Phytoremediation for heavy metal-contaminated soils combined with bioenergy production. Journal of Environmental Engineering and Landscape Management, 15(4), pp. 227-236, 2007.

[24] Brooks, R.R., Chambers, M.F., Nicks, L.J. \& Robinson, B.H., Phytomining. Trends in Plant Science, 3(9), pp. 359-362, 1998. doi: http://dx.doi.org/10.1016/S1360-1385(98)01283-7

[25] Chaney, R.L. Li, Y.-M., Brown, S.L., Homer, F.A., Malik, M., Angle, J.S., Baker, A.J.M., Reeves, R.D. \& Chin, M., Chapter 7. Improving metal hyperaccumulator wild plants to develop commercial phytoextraction systems. Phytoremediation of Contaminated Soil and Water, ed. Norman Terry, CRC Press: Boca Raton, 2000, p. 408.

[26] Tang, M., Hu, F., Wu, L., Luo, Y., Jiang, Y., Tan, C., Li, N., Li, Z. \& Zhang, L., Effects of copper-enriched composts applied to copper-deficient soil on the yield and copper and zinc uptake of wheat. International Journal of Phytoremediation, 11(1), pp. 81-93, 2009. doi: http://dx.doi.org/10.1080/15226510802363535

[27] Qu, J., Yuan, X., Wang, X. \& Shao, P., Zinc accumulation and synthesis of ZnO nanoparticles using Physalis alkekengi L. Environmental Pollution, 159(7), pp. 1783-1788, 2010. doi: http:// dx.doi.org/10.1016/j.envpol.2011.04.016

[28] Thewys T. \& Kuppens, T., Economics of willow pyrolysis after phytoextraction. International Journal of Phytoremediation, 10(6), pp. 561-583, 2008. doi: http://dx.doi. org/10.1080/15226510802115141

[29] Meers, E., Vandecasteele, B., Ruttensc, A., Vangronsveld, J. \& Tack, F.M.G., Potential of five willow species (Salix spp.) for phytoextraction of heavy metals. Environmental and Experimental Botany, 60(1), pp. 57-68, 2007. doi: http://dx.doi.org/10.1016/j.envexpbot.2006.06.008

[30] Lievens, C., Yperman, J., Vangronsveld, J. \& Carleer, R., Study of the potential valorisation of heavy metal contaminated biomass via phytoremediation by fast pyrolysis: part I. Influence of temperature, biomass species and solid heat carrier on the behaviour of heavy metals. Fuel, 87(10-11), pp. 1894-1905, 2008.doi: http://dx.doi.org/10.1016/j.fuel.2007.10.021

[31] Chaney, R.L., Angle, J.S., Baker, A.J.M. \& Li, Y.M., Method for phytomining of Nickel, Cobalt and other metals from soils. US Patent, 5, pp. 711-784, 1998.

[32] Grison, C. \& Escarré, J., Utilisation de plantes accumulatrices d'éléments traces métalliques pour la mise en oeuvre de réactions chimiques. International Patent WO 2011/064462, Juin 3, 2011.

[33] Grison, C. \& Escarré, J., Utilisation de plantes accumulatrices d'éléments traces métalliques pour la mise en oeuvre de réactions chimiques. International Patent WO 2011/064487, juin 3, 2011.

[34] Losfeld, G.,Vidal de la Blache, P., Escande, V. \& Grison, C., Lewis acid catalysts: a potential exploitation for zinc and nickel phytoextraction. Environmental Impact, WIT Press: Southampton, 2012. 
[35] Shirakashi, T. \& Kubo, T., Cation distribution in franklinite by nuclear magnetic resonance. American Mineralogist, 64(5-6), pp. 599-603, 1979.

[36] Pence, N.S., Larsen, P.B., Ebbs, S.D., Letham, D.L.D., Lasat, M.M., Garvin, D.F., Eide, D. \& Kochian, L.V., The molecular physiology of heavy metal transport in the $\mathrm{Zn} / \mathrm{Cd}$ hyperaccumulator Thlaspi caerulescens. Proceedings of the National Academy of Science of the United States of America, 97(9), pp. 4956-4960, 2000. doi: http://dx.doi.org/10.1073/pnas.97.9.4956

[37] Tolrà, R.P., Poschenrieder, C. \& Barceló, J., Zinc hyperaccumulation in Thlaspi caerulescens. II. Influence on organic acids. Journal of Plant Nutrition, 19(12), pp. 1541-1550, 1996. doi: http://dx.doi.org/10.1080/01904169609365220

[38] Jaffré, T., Perrier, N., Colin, F., Ambrosia, J.-P., Roseb, J. \& Bottero, J.-Y., Nickel speciation in Sebertia acuminata, a plant growing on a lateritic soil of New Caledonia. Surface Geosciences (Pedology), 336(6), pp. 567-577, 1976.

[39] European Commission, Reach in Brief. Environmental Directorate General, 2007.

[40] Anastas, P.T. \& Warner, J.C., Green Chemistry: Theory and Practice, Oxford University Press: New York, 1998.

[41] Anastas, P.T., Kirchhoff, M.M. \& Williamson, T.C., Catalysis as a foundational pillar of green chemistry. Applied Catalysis A: General, 221(1-2), pp. 3-13, 2001doi: http:://dx.doi. org/10.1016/S0926-860X(01)00793-1

[42] Doble, M. \& Kruthienti, A. K., Green Chemistry and Engineering, 1st edn., Elsevier: New York, 2007.

[43] Tundo, P., Perosa, A. \& Zecchini, F., Methods and Reagents for Green Chemistry. Wiley: USA, 2007. doi: http://dx.doi.org/10.1002/9780470124086

[44] Friedel, C. \& Crafts, J.M., Sur une nouvelle méthode générale de synthèse d'hydrocarbures, d'acétones. Comptes rendus hebdomadaires des séances de l'Académie des sciences, 84, pp. 1392-1395, 1877.

[45] Dasgupta, S. \& Török, B., Environmentally benign contemporary Friedel-Crafts chemistry by solid acids. Current Organic Synthesis, 5(4), pp. 321-342, 2008. doi: http://dx.doi. org/10.2174/157017908786241572

[46] Clark, J.H. \& Macquarrie, D.J., Heterogeneous catalysis in liquid phase transformations of importance in the industrial preparation of fine chemicals. Organic Process Research \& Development, 1(2), pp. 149-162, 1997. doi: http://dx.doi.org/10.1021/op960008m

[47] Corma, A. \& Garcia, H., Lewis acids: from conventional homogeneous to green homogeneous and heterogeneous catalysis. Chemical Reviews, 103(11), pp. 4307-4366, 2003. doi: http:// dx.doi.org/10.1021/cr030680z

[48] Van den Eynde, J.-J., Mayence, A. \& van Haverbeke, Y., Ultrasound promoted benzylation of arenes in the presence of zinc chloride mixed with a K10 clay. Tetrahedron Letters, 36(18), pp. 3133-3136, 1995. doi: http://dx.doi.org/10.1016/0040-4039(95)00472-O

[49] Cseri, T., Békássy, S., Figueras, F. \& Rizner, S., Benzylation of aromatics on ion-exchanged clays. Journal of Molecular Catalysis A: Chemical, 98(2), pp. 101-107, 1995. doi: http:// dx.doi.org/10.1016/1381-1169(95)00016-X

[50] Choudhary, V.R., Jhaa, R. \& Narkhedea, V.S., In-Mg-hydrotalcite anionic clay as catalyst or catalyst precursor for Friedel-Crafts type benzylation reactions. Journal of Molecular Catalysis A: Chemical, 239(1-2), pp. 76-81, 2005. doi: http://dx.doi.org/10.1016/j.molcata.2005.06.003

[51] Spagnol, M., Gilbert, L., Benazzi, E. \& Marcilly, C., Procédé d'acylation d'éthers aromatiques. Brevet Européen PCT/FR96/00717, 1998.

[52] Gupta, R., Kumar, V., Gupta, M., Paul, S. \& Gupta, R., Silica supported zinc chloride catalyzed acetylation of amines, alcohols and phenols. Indian Journal of Chemistry, 47(B), pp. 1739-1743, 2008. 